\title{
Joint stability of internal conical connection abutments with or without hexagon indexes: an in vitro study
}

\author{
Sang-Woon Lee 1 , Min-Sang Cha1, Ji-Hye Lee ${ }^{2}$, Lee-Ra Cho², Chan-Jin Park²* \\ 'Department of Dentistry, Gangneung Asan Hospital, University of Ulsan, College of Medicine, Gangneung, Republic of Korea \\ ${ }^{2}$ Department of Prosthodontics and Research Institute of Oral Science, Gangneung-Wonju National University, Gangneung, \\ Republic of Korea
}

Purpose: The purpose of this study was to compare the axial displacement of the hexagonal and conical abutment in internal conical connection implant after screw tightening and cyclic loading. Materials and Methods: Internal conical connection implants were divided into two groups $(n=10)$ : group HEX, hexagonal abutment; and group CON, conical 2-piece abutments. The axial displacement and removal torque values were measured after $30 \mathrm{Ncm}$ torque tightening and 250N loading test of 100,000 cycles. The Student $t$ test with $5 \%$ significance level was used to evaluate the data. Results: HEX group demonstrated significantly higher axial displacement values after $30 \mathrm{Ncm}$ tightening in comparison to the CON group $(P<0.05)$. No significant difference was found in axial displacement after cyclic loading $(P=0.052)$. Removal torque loss before and after the cyclic loading both revealed no significant difference between groups $(P=0.057$ and $P=0.138)$. Removal torque value decreased after cyclic loading in both groups $(P<0.05)$. Conclusion: Overall, both abutment with or without hexagon index presented similar biomechanical performance except HEX group demonstrated significantly more axial displacement after applying tightening torque. (J Dent Rehabil Appl Sci 2020;36(2):95-103)

Key words: morse taper dental implant-abutment interface; dental abutment; hexagon index; axial displacement; removal torque value

\section{Introduction}

The appropriate choice of particular implant (internal or external) and abutment system (1-piece or 2-piece, hexagon or non-hexagon) is essential to successful outcomes. ${ }^{1}$ Among various implant systems, internal conical connection systems are reported to demonstrate superior bending force resistance and fatigue resistance..$^{2-4}$ The tapered conical interfaces become wedged as inner abutment conical area compresses into implant. ${ }^{5}$ High frictional resistance from conical implant-abutment contact compensate the high stress concentration to abutment screw, which

*Correspondence to: Chan-Jin Park

Professor, Department of Prosthodontics and Research Institute of Oral Science, Gangneung-Wonju National University, 7, Jukheon-gil, Gangneung, 25457, Republic of Korea

Tel: +82-33-640-3153, Fax: +82-33-640-3103, E-mail: doctorcj@gwnu.ac.kr

Received: May 27, 2020/Last Revision: May 28, 2020/Accepted: May 28, 2020 leads to protect the preload of abutment screw than the other implant systems. ${ }^{6}$

Recently, concern about the preload loss in internal conical connection originated from axial displacement of the abutment has been reported. ${ }^{7}$ Tightening the screw and functional loading fully transfer the compressive force which intrudes the tapered portion of the abutment inside the implant, inducing axial displacement. ${ }^{8,9}$ Axial displacement of abutment upon functional loading restores the elongated abutment screw resulting in preload loss, even a screw loosening. ${ }^{10}$ Mechanical analysis of relationship between removal torque values and axial displacement

Copyright@ 2020 The Korean Academy of Stomatognathic Function and Occlusion. (c) It is identical to Creative Commons Non-Commercial License. 
is essential to prevent its prosthetic complications, especially in cement-retained prosthesis which can become the prosthesis failure after screw loosening. ${ }^{11}$

Factors affecting the preload have been focused on physical properties of abutment screw such as the material, surface treatment, frictional resistance, sufficient insertion torque, ${ }^{12,13}$ and re-tightening sequence. ${ }^{14}$ In internal conical connections, the function of friction between abutment-implant is also responsible for retention of abutment. ${ }^{15,16} \mathrm{Sev}$ eral in vitro studies evaluating the influence of the abutment-implant conical connection to preload, presented the decreased preload of abutment screw after cyclic loading in 2-piece abutment. ${ }^{14,15,17-21} \mathrm{Re}$ duced preload of abutment screw might be compensated by the intimate wedging from conical contact area, demonstrated as increased traction force ${ }^{15,21}$ or increase in axial dispacemet. ${ }^{14,18}$ Due to the different loading vector of the force and loading conditions, it is hard to compare different studies equivalently. To clarify the relationship between axial displacement and loss of preload, other factors affecting screw joint stability should be controlled and evaluated.

Internal conical connection system has various polygonal indices such as triangular, rectangular, hexagonal, octagonal, dodecagonal shape with different taper angle $\left(7^{\circ}, 8^{\circ}, 11^{\circ}\right)$ from different manufacturers. Polygonal indexed abutment system with individual abutment screw serves as anti-rotational effect and facilitates reposition of the abutment during impression and maintenance period. During functional loading, anti-rotational feature cannot provide significant contribution because the machining tolerance and the parallel design of the index cannot achieve functional contact between implant-abutment. ${ }^{22}$ Various mechanical analysis has been evaluated the influence of polygonal index regarding stress distribution, ${ }^{16,22-25}$ microgap formation, ${ }^{26}$ fatigue resistance, ${ }^{22}$ removal torque value. ${ }^{27}$

When focused in internal conical connection with hexagon index and 11-degree conical taper design, relatively scarce stress distribution and mechanical strength has been studied. Stress-distribution studies comparing abutments with indexed abutment need to be interpreted carefully. Although the hexagon index does not contact implant, studies reported identical or more even stress distribution in hexagon indexed abutment with conical abutment because of the assumption that hexagon index contact with the implant. ${ }^{24,26}$ Another study assumed the hexagon index does not contact with implant and reported more downward stress distribution in conical abutment which is more advantageous stress distribution in conical abutment than hexagon abutment. ${ }^{23}$

Most of the comparative studies evaluating the effect of hexagon index abutment compared it to conical 1-piece abutment. When comparing 1-piece abutment with hexagon 2-piece abutment, better stress distribution to implant and surrounding bone, ${ }^{25}$ superior static bending strength, ${ }^{4}$ better fatigue resistance, ${ }^{28}$ less preload loss ${ }^{19}$ has been reported in 1 -piece abutment. Regarding the superior maintenance of preload of the abutment, 1-piece abutment has broader contact area which can increase frictional resistance. The frictional resistance from 1-piece abutment can also restrict axial displacement of itself. ${ }^{18}$ Recent in vitro study reported significantly less initial torque loss in 1-piece abutment right after screw tightening, but no differences were found after cyclic loading. ${ }^{29}$ On the contrary, after thermocyclic loading, more than half of the preload loss was reported in hexagon indexed abutment while 1-piece abutment revealed less than $14 \%$ of the preload loss. ${ }^{30}$ To evaluate the effect of hexagon index, 2-piece abutment without hexagon index also need to be evaluated .

Compared with 1-piece abutment, 2-piece nonhexagon abutment has identical contact implantabutment interface, but the axial displacement is not restricted from rotational friction and more axial displacement is anticipated. ${ }^{15}$ The 2 -piece conical abutment (Fig. 1) has been introduced for multiple prosthesis to enable screw-retightening and achieve prosthesis retrievability. No studies has been evaluated the axial displacement and removal torque loss of 2-piece conical abutment compared to the hexagon one.

The aim of this study was to evaluate the influence of hexagon index to axial displacement and removal torque value of implant-abutment assembly after 
A

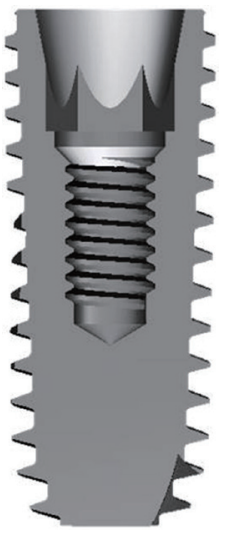

B

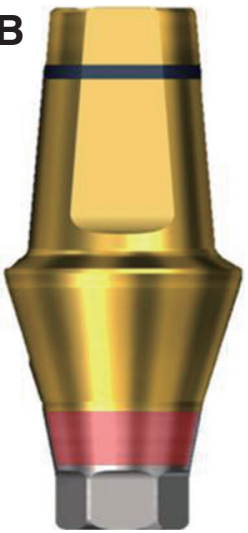

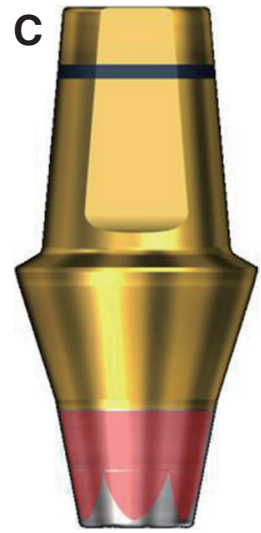

D

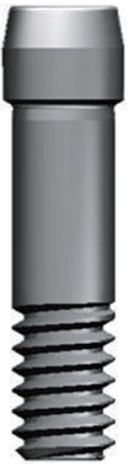

Fig. 1. Implant-abutment assemblies. (A) Implant, (B) Abutment with hexagon index, (C) Abutment without hexagon index, (D) Abutment screw.

cyclic loading in internal conical connection system. The first null hypothesis was that the axial displacement would not differ for abutment with or without hexagon index. The second null hypothesis was that removal torque value would not differ for each group before and after cyclic loading.

\section{Materials and Methods}

A commercially available internal conical connection implant system (Luna; Shinhung, Seoul, Korea) was prepared. Implants with identical length $(10 \mathrm{~mm})$ and diameter (Ø 4.0) were used (Fig. 1A). A 2-piece abutment (Duo Abutment; Shinhung, Seoul, Korea) with hexagon index (HEX) or without hexagon index $(\mathrm{CON})$ were prepared using identical abutment screw (Ti abutment screw; Shinhung, Seoul, Korea) (Fig. 1). Ten specimens of each of the HEX and CON groups of implants were prepared. The implant/abutment complex was assembled with an abutment screw using a digital torque gauge (SERIES TT03; Mark-10 Inc., New York, USA) with 10-Ncm as a baseline and $30-\mathrm{Ncm}$ tightening twice in 10-minute intervals. ${ }^{31}$ The implant was securely fastened in a friction grip vise $3 \mathrm{~mm}$ below the implant platform to simulate the bone loss, and a metal cap was engaged on the abutment to simulate the clinical crown (Fig. 2). ${ }^{7}$ The measuring area of the implant/abutment complex was protected by the metal cap or vise to avoid any change during loading cycles. The axial cyclic load was applied using a universal testing machine (ElectroPlus E3000; Instron, Washington DC, USA). Each implant/abutment pair with the same composition was tested for vertical loads of $250 \mathrm{~N}$ for 100,000 cycles. The total length of the implant/ abutment complex and reverse torque value of the abutment screw was recorded before and after cyclic load using an electronic digital micrometer (Series 293; Mitutoyo, Tokyo, Japan) (Fig. 3).

The removal torque loss was calculated according to the following formula.

Removal torque loss $(\%)=$ (Initial removal torque value - Postload removal torque value) / Initial removal torque value $\times 100$

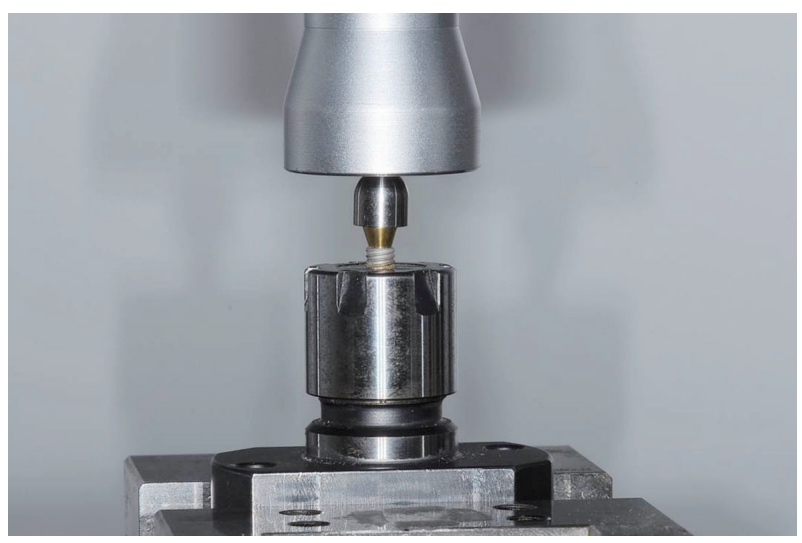

Fig. 2. Implant-abutment assembly loaded with metal cap and positioned with collet chuck for vertical cyclic loading test. 


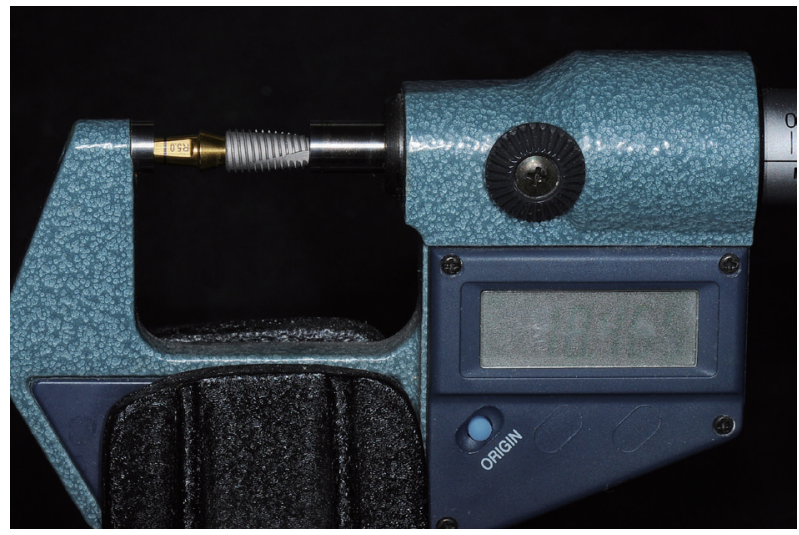

Fig. 3. Measurement of axial displacement.

Comparison between the HEX and CON group was analyzed with the Student $t$ test $(\alpha=0.05)$. Removal torque values before and after cyclic loading was analyzed by using the Student paired $t$ test $(\alpha=$ $0.05)$.

\section{Results}

Kolmogorov-Smirnov test results demonstrated normal distribution of the axial displacement and removal torque value $(P=0.410)$. The mean axial displacement $(\mu \mathrm{m})$ of the abutment and removal torque loss $(\%)$ is presented in Table 1 and 2. There was significantly more axial displacement in HEX group than CON group after screw tightening $(P<0.05)$.
No significant difference was found in axial displacement after cyclic loading $(P=0.052)$. Removal torque loss before and after the cyclic loading both revealed no significant difference between groups $(P=0.057$ and $P=0.138)$. Removal torque decreased after cyclic loading in both groups $(P<0.05$, Table 2$)$.

\section{Discussion}

The first null hypothesis was rejected because a significant more axial displacement demonstrated with hexagon index $(P<0.05)$. The second null hypothesis was accepted because removal torque value demonstrated no significant differences after cyclic loading $(P>0.05)$.

The results showed that a certain amount of axial displacement of abutment was inevitable. The HEX group showed significantly large axial displacement after tightening torque has been applied. Implant system tested in this study has longer, larger implantabutment contact area in CON group when compared with HEX group (Fig. 1). As tightening torque is applied, the abutments transfer frictional force into the implant and broader mating surface distribute more frictional resistance. ${ }^{16}$ In stress distribution, longer abutment contact in conical abutment demonstrated more deeper stress concentration. ${ }^{23}$ Similar study compared 2-piece abutment with or without hexagon index and large traction force was required

Table 1. Mean axial displacement of abutment $(\mu \mathrm{m})$ and removal torque value $(\mathrm{N})$ after abutment screw tightening and 250 N cyclic loading (Unit: $\mu \mathrm{m})$

\begin{tabular}{|c|c|c|c|c|c|}
\hline & Group & Screw tightening (Mean (SD)) & $P$ & Cyclic loading (Mean (SD)) & $P$ \\
\hline \multirow{2}{*}{ Axial displacement } & HEX & $37.2(2.48)$ & $<0.001$ & $5.0(2.40)$ & 0.052 \\
\hline & $\mathrm{CON}$ & $28.1(4.09)$ & & $3.3(0.94)$ & \\
\hline
\end{tabular}

Table 2. Mean removal torque value $(\mathrm{N})$ and removal torque loss (\%) after abutment screw tightening and $250 \mathrm{~N}$ cyclic loading

\begin{tabular}{|c|c|c|c|c|c|}
\hline & Group & Screw tightening (Mean (SD)) & $P$ & Cyclic loading (Mean (SD)) & $P$ \\
\hline \multirow{2}{*}{ Removal torque value $(\mathrm{Ncm})$} & HEX & $21.0(2.06)$ & 0.057 & $14.8(1.89)$ & 0.138 \\
\hline & $\mathrm{CON}$ & $23.4(3.10)$ & & $16.2(2.07)$ & \\
\hline$P$ value between groups & & & & & $<0.001$ \\
\hline \multirow{2}{*}{ Removal torque loss (\%) } & HEX & $29.93(6.86)$ & & $42.25(28.77)$ & \\
\hline & $\mathrm{CON}$ & $21.93(10.36)$ & & $29.61(14.76)$ & \\
\hline
\end{tabular}


to dislodge abutment in conical abutment compared with hexagon one. ${ }^{21}$ Broader contact surface of the CON abutment disperse compressive force more evenly with relatively less interfacial settling and elastic deformation, which could also lead to less axial displacement.

After cyclic loading, the magnitude of axial displacement was so minute in HEX and CON group demonstrated no difference between groups. The removal torque value did not demonstrate significant difference between HEX and CON groups. Most of the axial displacement has been demonstrated after tightening torque. Most of the compressive loads which intrude the abutment are generated upon applying preload to the abutment screw within yield strength. ${ }^{32,33}$ Concerns has been made about the axial displacement induced from functional loading because it could produce uncontrolled axial discrepancy of prosthesis or loss of occlusal contact. ${ }^{7,8}$ Although both groups demonstrated stable axial position after loading with minute displacement, relatively large standard deviation of hexagon abutment displacement was observed. It could implicate conical abutment might reach steady state of its vertical position after screw tightening and remain more stable upon functional loading.

Initial torque value decreased in both groups. Due to the frictional resistance and sedimentation effect of abutment screw, ${ }^{34}$ up to $90 \%$ of the tightening torque has been reported to diminish. ${ }^{35}$ To obtain desired preload, abutment screw material, surface treatment, frictional resistance, sufficient insertion torque, ${ }^{12,13}$ and re-tightening sequence ${ }^{14}$ has been improved. Recent advances in precise milling technique, screw design and material improved screw preload retention demonstrating 7 - 14\% of removal torque loss. ${ }^{14,21}$ Those reported ranges are similar to our initial torque loss results. In implant-abutment interface, the conical surface offers more frictional resistance lead to more loss of preload. ${ }^{14}$ Clinically, abutment screw retightening in 10 minutes interval is essential. ${ }^{31}$

Our study demonstrated no significant differences between HEX and CON group, which is identical to another study compared 2-piece conical abutment with hexagon abutment. ${ }^{21}$ Other studies also dem- onstrated initial torque loss with more initial torque loss in hexagon abutment, which was compared with 1-piece abutment. ${ }^{29,36}$ Relatively large initial torque loss in 2-piece abutment was reported in comparison with 1-piece one. In addition to the preload of the abutment screw, 1-piece abutment might generate additional frictional resistance from intimate abutmentimplant interface upon removal. On the other hand, once the 2-piece abutment is settled with tightening torque, preload is retained only in abutment screw and it demonstrated no difference with or without hexagon index.

After cyclic loading, axial displacement of abutment occurred and removal torque value decreased in abutment screw. Recently, studies reported similar results of preload loss along with axial displacement after loading. ${ }^{14,18,20,37}$ Compared to our experimental condition, studies using hexagon abutment and cyclic loading of $250 \mathrm{~N}$ condition both demonstrated less than $30 \%$ loss of preload under vertical ${ }^{18}$ and oblique $^{14}$ loading condition. Another comparable study using conical abutment and vertical static loading of $800 \mathrm{~N}$ reported loss of removal torque value up to $89 \%{ }^{7}$ Because of the different experimental conditions, existence of hexagon index and other factors affecting abutment screw preload such as component material, surface roughness and screw design, might hinder the appropriate comparison from each studies. Our study resulted in no significant difference after cyclic loading between HEX and CON group which is in accordance with other comparison studies comparing the effect of hexagon index. ${ }^{21,29}$ Whether the complex functional loading condition hinders the effect of hexagon index or the existence of hexagon index is so minute that could be ignored need further studies.

It is clear that axial displacement of abutment under functional loading restores the elongated abutment screw which reduces preload. Loss of preload could be improved after re-tightening procedure. ${ }^{14}$ When removal torque loss occur, abutment screw loosening might act as crow bar inside the implant which could lead to micromotion of the abutmen. ${ }^{38}$ Compared with conical abutment, hexagon index could be exposed to excessive stress concentration, 
which is more prone to fracture. ${ }^{24,26}$ Periodic re-tightening of abutment screw is generally recommended to prevent those complications. ${ }^{14}$ Further evaluation for the timing and interval of re-tightening about hexagon and conical abutment is still required.

\section{Conclusion}

Within the limitation of this in vitro study, the use of conical abutment demonstrated significantly less axial displacement after applying tightening torque. However, the axial displacement after cyclic loading, removal torque values before and after cyclic loading did not demonstrate difference between abutment groups. After cyclic loading, axial displacement was quite minute, however, removal torque value decreased significantly.

Overall, both abutment with or without hexagon index presented similar biomechanical performance.

\section{ORCID}

Sang-Woon Lee https://orcid.org/0000-0002-0904-9391 Min-Sang Cha https://orcid.org/0000-0003-1695-0142 Ji-Hye Lee https://orcid.org/0000-0002-1040-061X Lee-Ra Cho https://orcid.org/0000-0003-3989-2870 Chan-Jin Park https://orcid.org/0000-0003-4734-214X

\section{References}

1. Cehreli MC, Akça K, Iplikçioğlu H, Sahin S. Dynamic fatigue resistance of implant-abutment junction in an internally notched morse-taper oral implant: influence of abutment design. Clin Oral Implants Res 2004;15:459-65.

2. Norton MR. An in vitro evaluation of the strength of an internal conical interface compared to a butt joint interface in implant design. Clin Oral Implants Res 1997;8:290-8.

3. Norton MR. Assessment of cold welding properties of the internal conical interface of two commercially available implant systems. J Prosthet Dent 1999;81:159-66.

4. Norton MR. An in vitro evaluation of the strength of a 1-piece and 2-piece conical abutment joint in implant design. Clin Oral Implants Res 2000;11:45864.

5. Budynas RG, Nisbett JK. Shigley's mechanical engineering design. 9th ed. New York; McGraw-Hill; 2011.

6. Schmitt CM, Nogueira-Filho G, Tenenbaum HC, Lai JY, Brito C, Döring H, Nonhoff J. Performance of conical abutment (Morse Taper) connection implants: a systematic review. J Biomed Mater Res A 2014;102:552-74.

7. Lee JH, Lee W, Huh YH, Park CJ, Cho LR. Impact of intentional overload on joint stability of internal implant-abutment connection system with different diameter. J Prosthodont 2019;28:e649-e56.

8. Lee JH, Kim DG, Park CJ, Cho LR. Axial displacements in external and internal implant-abutment connection. Clin Oral Implants Res 2014;25:e83-9.

9. Seol HW, Heo SJ, Koak JY, Kim SK, Kim SK. Axial displacement of external and internal implantabutment connection evaluated by linear mixed model analysis. Int J Oral Maxillofac Implants 2015;30:1387-99.

10. Schwarz MS. Mechanical complications of dental implants. Clin Oral Implants Res 2000;11 Suppl 1:156-8.

11. Guzaitis KL, Knoernschild KL, Viana MA. Effect of repeated screw joint closing and opening cycles on implant prosthetic screw reverse torque and implant and screw thread morphology. J Prosthet Dent 2011;106:159-69.

12. Xia D, Lin H, Yuan S, Bai W, Zheng G. Dynamic fatigue performance of implant-abutment assemblies with different tightening torque values. Biomed Mater Eng 2014;24:2143-9.

13. Bernardes SR, da Gloria Chiarello de Mattos M, Hobkirk J, Ribeiro RF. Loss of preload in screwed implant joints as a function of time and tightening/ untightening sequences. Int J Oral Maxillofac Implants 2014;29:89-96.

14. Cho WR, Huh YH, Park CJ, Cho LR. Effect of cyclic loading and retightening on reverse torque value in external and internal implants. J Adv Prosthodont 2015;7:288-93.

15. Pintinha M, Camarini ET, Sábio S, Pereira JR. Effect of mechanical loading on the removal torque 
of different types of tapered connection abutments for dental implants. J Prosthet Dent 2013;110:3838.

16. Ding TA, Woody RD, Higginbottom FL, Miller BH. Evaluation of the ITI Morse taper implant/ abutment design with an internal modification. Int J Oral Maxillofac Implants 2003;18:865-72.

17. Ricciardi Coppede A, de Mattos Mda G, Rodrigues RC, Ribeiro RF. Effect of repeated torque/mechanical loading cycles on two different abutment types in implants with internal tapered connections: an in vitro study. Clin Oral Implants Res 2009;20:624-32.

18. Kim KS, Han JS, Lim YJ. Settling of abutments into implants and changes in removal torque in five different implant-abutment connections. Part 1: Cyclic loading. Int J Oral Maxillofac Implants 2014;29:1079-84.

19. Martins CM, Ramos EV, Kreve S, de Carvalho GAP, Franco ABG, de Macedo LGS, de Moura Silva A, Dias SC. Reverse torque evaluation in indexed and nonindexed abutments of Morse Taper implants in a mechanical fatigue test. Dent Res J (Isfahan) 2019;16:110-16.

20. Piermatti J, Yousef H, Luke A, Mahevich R, Weiner S. An in vitro analysis of implant screw torque loss with external hex and internal connection implant systems. Implant Dent 2006;15:427-35.

21. de Oliveira Silva TS, Mendes Alencar SM, da Silva Valente V, de Moura C. Effect of internal hexagonal index on removal torque and tensile removal force of different Morse taper connection abutments. J Prosthet Dent 2017;117:621-27.

22. Perriard J, Wiskott WA, Mellal A, Scherrer SS, Botsis J, Belser UC. Fatigue resistance of ITI implantabutment connectors - a comparison of the standard cone with a novel internally keyed design. Clin Oral Implants Res 2002;13:542-9.

23. Cho SY, Huh YH, Park CJ, Cho LR. Three-dimensional finite element analysis on stress distribution of internal implant-abutment engagement features. Int J Oral Maxillofac Implants 2018;33:319-27.

24. Cho SY, Huh YH, Park CJ, Cho LR. Three-dimensional finite element analysis of the stress distribution at the internal implant-abutment connection. Int J Periodontics Restorative Dent 2016;36:e49-58.
25. Anami LC, da Costa Lima JM, Takahashi FE, Neisser MP, Noritomi PY, Bottino MA. Stress distribution around osseointegrated implants with different internal-cone connections: photoelastic and finite element analysis. J Oral Implantol 2015;41:155-62.

26. Saidin S, Abdul Kadir MR, Sulaiman E, Abu Kasim NH. Effects of different implant-abutment connections on micromotion and stress distribution: prediction of microgap formation. J Dent 2012;40: 467-74.

27. Squier RS, Psoter WJ, Taylor TD. Removal torques of conical, tapered implant abutments: the effects of anodization and reduction of surface area. Int J Oral Maxillofac Implants 2002;17:24-7.

28. Kwon TK, Yang JH, Kim SH, Han JS, Lee JB. A comparative study of the 1-piece and 2-piece conical abutment joint: the strength and the fatigue resistance. J Korean Acad Prosthodont 2007;45:78086.

29. Cerutti-Kopplin D, Rodrigues Neto DJ, Lins do Valle A, Pereira JR. Influence of reverse torque values in abutments with or without internal hexagon indexes. J Prosthet Dent 2014;112:824-7.

30. Villarinho EA, Cervieri A, Shinkai RS, Grossi ML, Teixeira ER. The effect of a positioning index on the biomechanical stability of tapered implant-abutment connections. J Oral Implantol 2015;41:13943.

31. Siamos G, Winkler S, Boberick KG. Relationship between implant preload and screw loosening on implant-supported prostheses. J Oral Implantol 2002;28:67-73.

32. Bozkaya D, Müftü S. Mechanics of the tapered interference fit in dental implants. J Biomech 2003;36: 1649-58.

33. Bozkaya D, Müftü S. Mechanics of the taper integrated screwed-in (TIS) abutments used in dental implants. J Biomech 2005;38:87-97.

34. Binon PP. Evaluation of the effectiveness of a technique to prevent screw loosening. J Prosthet Dent 1998;79:430-2.

35. Haack JE, Sakaguchi RL, Sun T, Coffey JP. Elongation and preload stress in dental implant abutment screws. Int J Oral Maxillofac Implants 1995;10:52936. 
36. da Silva Prado L, da Silva J, Garcia ALH, Boaretto FBM, Grivicich I, Conter LU, de Oliveira Salvi A, Reginatto FH, Vencato SB, de Barros Falcão Ferraz A, Picada JN. Evaluation of DNA damage in HepG2 cells and mutagenicity of garcinielliptone FC, a bioactive benzophenone. Basic Clin Pharmacol Toxicol 2017;120:621-27.

37. Lee JH, Huh YH, Park CJ, Cho LR. Effect of the coronal wall thickness of dental implants on the screw joint stability in the internal implant-abutment connection. Int J Oral Maxillofac Implants 2016;31:1058-65.

38. Karl M, Taylor TD. Effect of cyclic loading on micromotion at the implant-abutment interface. Int J Oral Maxillofac Implants 2016;31:1292-7. 


\section{내부연결 원추형 임플란트의 육각구조의 유무에 따른 연결부 안정성: 실험적 연구}

이상운 ${ }^{1}$ 조교수, 차민상 ${ }^{1}$ 부교수, 이지혜 $\left.\right|^{2}$ 임상강사, 조리라 ${ }^{2}$ 교수, 박찬진 ${ }^{2 *}$ 교수

${ }^{1}$ 울산대학교 의과대학 강릉아산병원 치과

${ }^{2}$ 강릉원주대학교 치과대학 치과보철학교실 및 구강과학연구소

목적: 본 연구의 목적은 내부연결 원추형 임플란트의 육각구조 유무가 임플란트 지대주 장축변위와 임플란트 지대주 나 사의 풀림토크에 미치는 영향을 평가하고자 하였다.

연구 재료 및 방법: 내부연결 원추형 임플란트를 육각구조를 가진 지대주 그룹(HEX)과 육각구조를 갖지 않는 지대주 그 룹(CON)으로 나누고 각 그룹 당 10 쌍의 시편을 체결하였다. 지대주 나사를 $30 \mathrm{Ncm}$ 조임회전력을 가하여 체결한 뒤 장 축변위 및 풀림토크값을 측정하고 $250 \mathrm{~N}$ 수직적 반복하중을 100,000 회 가한 뒤 장축변위 및 풀림토크값을 측정하였다. 각 단계마다 디지털 마이크로미터를 이용하여 임플란트 직경과 수직적 높이를 측정하였고 전자 토크게이지를 이용하여 풀림토크값을 측정하였다. 각 군간의 값의 유의차를 확인하기 위하여 독립 표본 $\mathrm{T}$ 검정을 이용하여 통계분석하였다 $(\alpha=$ 0.05).

결과: $\mathrm{HEX}$ 군은 조임회전력을 가한 뒤 유의하게 높은 장축변위를 나타내였다 $(P<0.05) . \mathrm{HEX}$ 군과 $\mathrm{CON}$ 군은 수직적 반복하중 후 장축변위에 유의한 차이를 보이지 않았다 $(P=0.052)$. HEX 군과 CON 군은 수직적 반복하중 전, 후 풀림 토크값 모두 유의한 차이를 보이지 않았다 $(P=0.057$ and $P=0.138)$. 모든 그룹에서 반복하중 후 풀림토크값 상실율이 증가하였다 $(P<0.05)$.

결론: 내부연결 원추형 임플란트에서 육각구조를 가진 경우 장축 변위가 더 컸으며, 그 외의 연결부 안정성은 유사하였 다. 모든 그룹에서 반복하중 후 풀림토크값 상실율이 증가하였다.

(구강회복응용과학지 2020;36(2):95-103)

주요어: 내부연결 원추형 임플란트; 임플란트 육각구조; 장축변위; 풀림토크값 상실

*교신저자: 박찬진

(25457)강원도 강릉시 죽헌길 7, 강릉원주대학교 치과대학 치과보철학교실

Tel: 033-640-3153 | Fax: 033-640-3103 | E-mail: doctorcj@gwnu.ac. kr

접수일: 2020년 5월 27일 | 수정일: 2020년 5월 28일 | 채택일: 2020년 5월 28일 